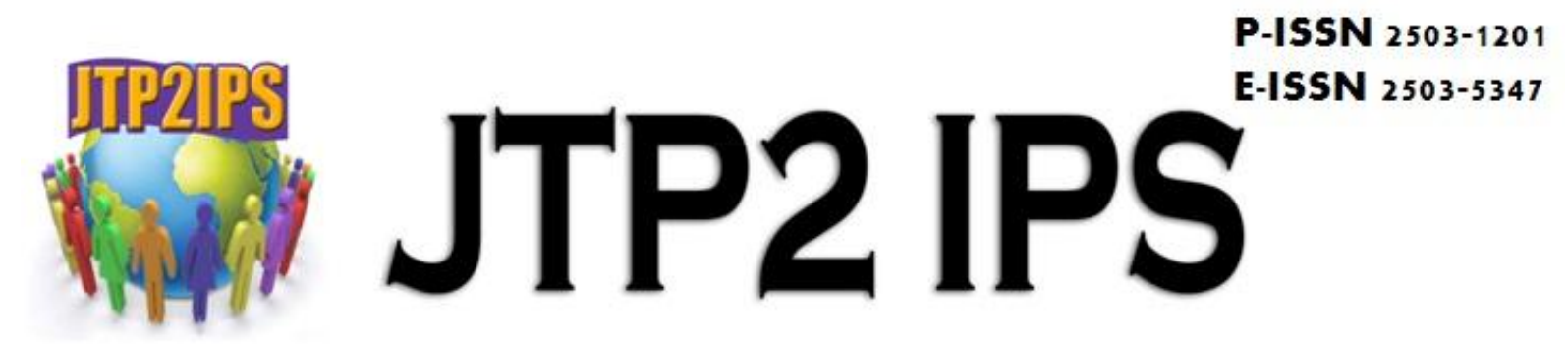

\title{
INTEGRASI NILAI BUDAYA ETNIS BUGIS MAKASSAR DALAM PROSES PEMBELAJARAN \\ SEBAGAI SALAH SATU STRATEGI MENGHADAPI ERA MASYARAKAT EKONOMI ASEAN (MEA)
}

\author{
Erman Syarif ${ }^{1}$, Sumarmi ${ }^{2}$, Ach Fatchan ${ }^{2}$, I Komang Astina ${ }^{2}$
}

\begin{abstract}
Abstrak
Tulisan ini bertujuan untuk mengkaji tentang integrasi nilai budaya etnis Bugis Makassar dalam pembelajaran Geografi Sosial sebagai salah satu strategi menghadapi Masyarakat Ekonomi Asean (MEA). Nilai budaya lokal merupakan sebuah isu penting yang seharusnya dikaji dalam pembelajaran Geografi Sosial. Menghadapi baru ini diperlukan berbagai strategi diantaranya dengan mengadopsi nilai budaya lokal dalam proses pembelajaran. Penanaman nilai-nilai budaya lokal dalam proses pembelajaran diharapkan akan mengimbangi pengaruh budaya asing yang semakin mewabah di masyarakat kita khususnya Sulawesi Selatan. Budaya Bugis Makassar sebagai salah satu budaya lokal yang tumbuh dan berkembang dikalangan masyarakat Bugis Makassar, memiliki unsur penting yang dapat meningkatkan motivasi belajar peserta didik, yaitu konsep Siri' dan Pacce. Konsep ini bila dimanfaatkan secara benar dalam proses pembelajaran dapat menjadi pendorong kuat bagi peserta didik untuk meningkatkan prestasi belajarnya
\end{abstract}

Kata Kunci :Integrasi, Budaya Lokal, Etnis Bugis Makassar, Geografi Sosial

\begin{abstract}
This paper aims to examine the integration of cultural values of ethnic Bugis Makassar in learning Social Geography as one of the strategies to face the Asean Economic Community (AEC). Local cultural values is an important issue that should be studied in study Social Geography. This new face is needed to adopt a variety of strategies including local cultural values in the learning process. Planting the values of the local culture in the learning process is expected to offset the influence of foreign culture that is increasingly prevalent in our society, especially South Sulawesi. Culture Bugis Makassar as one of the local culture that is growing and developing among the Bugis Makassar, has an important element that can increase the motivation of learners, namely the concept of Siri 'and Pacce. This concept when used correctly in the learning process can be a powerful incentive for students to improve their academic achievement.
\end{abstract}

Keywords: Integration, Local Culture, Ethnic Bugis Makassar, Social Geography

${ }^{1}$ Pasca Sarjana Program Studi Pendidikan Geografi - Universitas Negeri Malang, emankgiman@gmail.com ${ }^{2}$ Fakultas Ilmu Sosial- Universitas Negeri Malang 


\section{PENDAHULUAN}

Pengaruh modernisasi terhadap kehidupan berbangsa tidak dapat dipungkiri lagi, hal ini berdampak pada mengikisnya nilai budaya luhur bangsa kita. Menurut Joesoef (1982) menyatakan bahwa nilai budaya yang merupakan landasan karakter bangsa yang penting untuk ditanamkan dalam setiap individu, agar setiap individu mampu lebih memahami, memaknai, dan menghargai serta menyadari pentingnya nilai budaya dalam menjalankan setiap aktivitas kehidupan. Rasyid (2013) bahwa pelestarian kebudayaan daerah dan pengembangan kebudayaan nasional melalui pendidikan baik pendidikan formal maupun nonformal, dengan mengaktifkan kembali segenap wadah dan kegiatan pendidikan. Pendidikan dan budaya memiliki peran yang sangat penting dalam menumbuhkan dan mengembangkan nilai luhur bangsa, yang berdampak pada pembentukan karakter.

Keragaman etnis dan budaya memiliki potensi besar dalam pembangunan dan pengembangan pendidikan. Tilaar (1999) mengemukakan bahwa "pendidikan nasional di dalam era reformasi perlu dirumuskan suatu visi pendidikan yang baru yaitu membangun manusia dan masyarakat madani Indonesia yang mempunyai identitas berdasarkan kebudayaan nasional". Geertz (1992) "kebudayaan dibangun dari kebudayaan daerah yang tumbuh dan berkembang di setiap etnis". Keragaman budaya yang tumbuh dan berkembang pada setiap etnis seharusnya diakui eksistensinya dan sekaligus dapat dijadikan landasan dalam pendidikan.

Integrasi nilai-nilai budaya dalam proses pembelajaran memiliki arti penting dalam pembentukan kepribadian peserta didik. Menurut Hasan (1995) bahwa "sistem nilai yang terabaikan dalam proses pembelajaran meng-akibatkan ketimpangan intelektual dengan emosional peserta didik". Mulyana (2004) mengungkapkan bahwa "pendidikan sangat memerlukan penanaman nilai karena gejala-gejala kehidupan saat ini yang disebabkan oleh arus globalisasi berpotensi mengikis jati diri bangsa". Senada dengan Suharjo (2006) menjelaskan bahwa "melalui pendidikan di sekolah diharapkan akan menghasilkan manusia Indonesia yang berkualitas". Pemahaman nilai karakteristik daerah kepada peserta didik diharapkan dapat menjadi benteng yang tangguh dalam menghadapi dampak negatif dari arus global yaitu MEA.
Salah salah satu strategi dalam menghadapi Masyarakat Ekonomi Asean (MEA) dalam bidang pendidikan yakni menanamkan konsep nilai budaya lokal dalam pembelajaran. Menurut Warsi (2004) "budaya lokal sebagai upaya membangun identitas bangsa, dan sebagai penyeleksi (filter) dari pengaruh budaya asing". Munadi (2010) yang mengatakan bahwa "fungsi pendidikan adalah melestarikan tata sosial dan tata nilai yang ada dalam masyarakat dan sebagai agen pembaharuan sosial sehingga dapat mengantisipasi masa depan". Pembelajaran berbasis budaya lokal memegang peranan yang sangat penting bagi pembinanaan dan pembentukan sikap, mental dan moral manusia.

Dunia pendidikan menghadapi era Masyarakat Ekonomi Asean (MEA) harus mempersiapkan sumber daya manusia yang terampil, peka dan kritis. Menurut Wardiman (2011) mengatakan bahwa "era globalisasi menurut sumber daya manusia tangguh". Hal ini sejalan dengan Seock dan Chen Lin (2011) menyatakan "proses globalisasi akan membuat sejumlah orang untuk kembali pada etnisitas mereka, yaitu suatu proses untuk mencari sebuah identitas diri". Mengadosi nilai-nilai budaya untuk ditransformasikan dalam pembelajaran berperan sebagai sarana pengendalian diri dalam menghadapi tekanan ekonomi yang kita hadapi saat ini maupun menyongsong pemberlakuan Masyarakat Ekonomi ASEAN.

Menanamkan nilai-nilai budaya lokal dalam proses pembelajaran sangat penting untuk dilakukan. Gaffar (2004) bahwa "pendidikan bukan hanya sekedar menumbuhkan dan mengembangkan keseluruhan aspek kemanusiaan tanpa diikat dengan nilai, tetapi nilai itu merupakan pengikat dan pengaruh proses pertumbuhan dan perkembangan tersebut". Sauri (2010) berpendapat bahwa "nilai dan pendidikan merupakan dua hal yang satu sama lainnya tidak dapat dipisahkan, ketika pendidikan cenderung diperlakukan sebagai wahana transfer pengetahuan pun telah terjadi perambatan nilai yang setidaknya bermuara pada nilai-nilai kebenaran intelektual". Untuk menyeimbangkan kebutuhan moral dan intelektual, maka pendidikan membutuhkan nilai-nilai sebagai implementasinya.

Siri' sebagai inti budaya Bugis-Makassar memiliki potensi untuk dapat meningkatkan prestasi belajar siswa, sebab siri' merupakan pandangan hidup yang bertujuan untuk mening- 
katkan harkat, martabat dan harga diri, baik sebagai individu maupun sebagai makhluk sosial. Konsep lain yang erat kaitannya dengan siri' adalah pacce'/passe' yang merupakan wujud rasa solidaritas terhadap penderitaan orang lain. Rasa solidaritas mengandung makna keinginan membantu sesama manusia yang memiliki kesulitan dan penderitaan. Dalam kaitannya dengan pembelajaran, konsep pacce' ini dapat dijadikan landasan oleh dosen dalam membina kebersamaan dan motivasi kepada peserta didik yang mempunyai prestasi lebih baik untuk membantu peserta didik lainnya yang mengalami masalah dalam proses pembelajaran.

Pentingnya proses interaksi dalam proses pembelajaran. Atmi (2013) mengungkapkan bahwa "konsep pembelajaran merupakan suatu tempat guru dan siswa membangun lingkungan sosial yang interaktif, dengan tujuan utama meningkatkan proses pembelajaran". Dimyanti (2011) mengung-kapkan bahwa "pembelajaran merupakan proses interaksi peserta didik dengan pendidik dan sumber belajar pada suatu lingkungan belajar". Interaksi yang baik antara guru dengan siswa dan kelengkapan fasilitas sebagai sumber belajar dapat meningkatkan potensi peserta didik secara optimal.

Proses interaksi dalam pembelajaran tidak boleh mengabaikan keterlibatan faktor sosial budaya. Zamroni (2001) mengemukakan bahwa "untuk menemukan wajah ke Indonesaian dalam pendidikan, maka diperlukan kajian untuk memenuhi nilai-nilai dan orientasi budaya daerah yang memiliki nilai positif bagi praktek pendidikan". Untuk memenuhi kebutuhan tersebut diperlukan kajian dalam bidang pendidikan khususnya pembelajaran di kelas yang melibatkan unsur budaya.

Pembelajaran dikemas harus sesuai dengan karakteristik dan budaya peserta didik. Djahiri (1985) mengenai mengemukakan bahwa "apa yang telah dipelajari mempunyai potensi untuk dimanfaatkan dalam kehidupan, baik kehidupan pribadi maupun partisipasi dalam kehidupan bermasyarakat". Pembelajaran yang dikemas sesuai dengan karakteristik peserta didik, dengan begitu peserta didikakan menjadikan arus global menjadi tambahan kekayaan nilai sosio kultural tanpa menghilangkan nilai budaya daerah.

\section{PEMBAHASAN}

\section{Kebudayaan Bugis Makassar}

Karakter bangsa tidak bisa terlepas dari nilainilai budaya. Budaya didefinisikan sebagai seluruh aspek kehidupan manusia dalam masyarakat, yang diperoleh dengan cara belajar, termasuk pikiran dantingkah laku (Marvins, 1999). Begitu juga dengan yang dikatakan oleh Parsudi Suparlan (1981) bahwa budaya adalah keseluruhan pengetahuan manusia sebagai mahluk sosial, yang digunakan untuk menginterpretasikan dan memahami lingkungan yang dihadapi, dan untuk menciptakan dan mendorong terwujudnya kelakuan.

Etnis Bugis dan etnis Makassar adalah dua diantara empat etnis besar yang berada di Sulawesi Selatan. Pada hakekatnya kebudayaan dan pandangan hidup orang Bugis pada umumnya sama dan serasi dengan kebudayaan dan pandangan hidup orang Makassar. Oleh karena itu membahas tentang budaya Bugis sulit dilepaskan dengan pembahasan tentang budaya Makassar. Hal ini sejalan dengan pandangan Abdullah (1985) yang mengatakan bahwa dalam sistem keluarga atau dalam kekerabatan kehidupan manusia Bugis dan manusia Makassar, dapat dikatakan hampir tidak terdapat perbedaan. Lebih lanjut dikemukakan bahwa kedua kelompok suku bangsa ini (suku Bugis dan suku Makassar) pada hakekatnya merupakan suatu unit budaya. Sebab itu, apa yang berlaku dalam dunia manusia Bugis, berlaku pula pada manusia Makassar.

Kebudayaan Bugis-Makassar yang dimaksud disini adalah totalitas hasil pemikiran dan tingkah laku yang dimiliki oleh masyarakat BugisMakassar dan dapat diteruskan dari generasi ke generasi berikutnya melalui proses belajar. Hasil pemikiran tersebut berupa nilai-nilai budaya Bugis-Makassar yang telah diwujudkan dalam pola tingkah laku masyarakat Bugis-Makassar dalam kehidupan keseharian. Nilai-nilai budaya Bugis-Makassar yang dimaksud antara lain nilai kejujuran, nilai keadilan, nilai kecendekiawanan, nilai kepatutan (Rahim, 1992). Sedang Sikki (1998) mengemukakan nilai-nilai budaya Bugis Makassar sebagai berikut: nilai kesetiaan, nilai keberanian, nilai kebijaksanaan, etos kerja, kegotong-royongan, keteguhan, solidaritas, persatuan, keselarasan, dan musyawarah.

Di dalam kehidupan masyarakat Bugis Makassar terdapat nilai-nilai sosial yang memben- 
tuk kearifan lokal (local wisdom) dan telah dianut serta menjadi bagian dari kehidupan seharihari.

\section{Konsep Mengenai Budaya Sipakatau (Saling Menghargai)}

Saling Menghargai adalah konsep yang memandang setiap manusia sebagai manusia. Sipakatau yang bermakna saling menghargai sebagai individu yang bermartabat. Nilai-nilai Sipakatau menunjukkan bahwa budaya Bugis-Makassar memposisikan manusia sebagai makhluk ciptaan Tuhan yang mulia dan oleh karenanya harus dihargai dan diperlakukan secara baik. Semangat ini mendorong tumbuhnya sikap dan tindakan yang dimplementasikan dalam hubungan sosial yang harmonis yang ditandai oleh adanya hubungan intersubyektifitas dan saling menghargai sebagai sesama manusia. Penghargaan terhadap sesama manusia menjadi landasan utama dalam membangun hubungan yang harmonis antar sesama manusia serta rasa saling menghormati terhadap keberadaban dan jati diri bagi setiap anggota kelompok masyarakat.

Konsep nilai Sipakatau dalam budaya BugisMakassar memposisikan manusia sebagai makhluk ciptaan Tuhan yang mulia dan oleh karenanya harus dihargai dan diperlakukan secara baik yang diimplementasikan dalam hubungan sosial yang harmonis yang ditandai oleh adanya hubungan intersubyektifitas dan saling menghargai sebagai sesama pegawai maupun pegawai dengan atasan dalam penyelenggaraan pemerintahan yang berwibawa. Sipakatau (Saling Menghargai) adalah sebagai individu yang bermartabat.

Bangsa Indonesia tidak akan mungkin mengelak dari globalisasi. Yang bisa kita lakukan hanyalah meminimalisir dampak negatif globalisasi. Salah satu masalah utama dalam bidang pendidikan dan kebudayan adalah masalah identitas kebangsaan. Dengan derasnya arus globalisasi dikhawatirkan budaya bangsa, khususnya budaya lokal akan mulai terkikis. Budaya asing kini kian mewabah dan mulai mengikis eksistensi budaya lokal yang sarat makna. Agar eksistensi budaya lokal tetap kukuh, maka diperlukan pemertahanan budaya lokal.

\section{Konsep Mengenai Budaya Siri’ (Harga Diri/Rasa malu)}

Dari sekian banyak nilai-nilai budaya BugisMakassar yang disebutkan di atas, Siri' merupakan inti dari kebudayaan Bugis-Makassar. Mattulada (Marzuki, 1995) mengemukakan bahwa siri' tidak lain dari inti kebudayaan Bugis-Makassar. Konsep Siri' disepakati oleh para ahli dalam seminar siri' yang dilaksanakan di Makassarpada tahun 1977 sebagai berikut:

a. Siri' dalam sistem budaya, adalah pranata pertahanan harga diri, kesusilaan dan hukum serta agamasebagai salah satu nilai utama yang mempengaruhi dan mewarnai alam pikiran, perasaan dan kemauanmanusia.

b. Siri' dalam sistem sosial, adalah mendinamisasi keseimbangan eksistensi hubungan individu dan masyarakat untuk menjaga keseimbangan kekerabatan.

c. Siri' dalam sistem kepribadian adalah sebagai perwujudan konkret di dalam akal budi manusia yang menjunjung tinggi kejujuran, keseimbangan untuk menjaga harkat dan martabat manusia.

Dalam masyarakat Bugis-Makassar mempertahankan harga diri sebagai perwujudan dari konsep siri' merupakan suatu kewajiban setiap individu maupun kelompok, sebab kehilangan harga diri bagi masyarakat Bugis-Makassar identik dengan kehilangan ruhnya sebagai manusia. Manusia dalam masyarakat Bugis-Makassar hanya dapat dipandang sebagai manusia bila ia memiliki harga diri sebagai perwujudan dari siri'. Tanpa siri' manusia tidak ada bedanya dengan binatang. Dengan demikian siri' merupakan kebutuhan dasar manusia Bugis-Makassar dalam mempertahankan dan meme-lihara harkat dan martabat kemanusiaan.

Perwujudan dari konsep siri' menjadi daya pendorong yang kuat dalam berprestasi. Nur (2001) mengemukakan bahwa siswa yang selalu termotivasi untuk belajar sesuatu akan menggunakan proses kognitif yang lebih tinggi dalam mempelajari materi tertentu sehingga siswa tersebut akan menyerap dan mengendapkan materi pelajaran dengan lebih baik. Dalam hal ini siri' berfungsi sebagai motivasi dalam belajar, sedang motivasi belajar merupakan salah satu jalan dalam meningkatkan prestasi belajar.

Siri' merupakan perwujudan harga diri seorang manusia, maka pantang bagi manusia Bugis-Makassar untuk disinggung rasa harga dirinya (siri'nya). Dalam kaitannya dengan 
proses pembelajaran di kelas, maka seorang dosen hendaknya senantiasa berusaha menciptakan suasana yang kondusif agar peserta didik tidak tersinggung harga dirinya. Suasana kondusif ini merupakan hal yang perlu diperhatikan oleh dosen, sehingga peserta didik dapat memaksimalkan fungsi otaknya dalam proses pembelajaran. Marpaung (2003) menge-mukakan bahwa bila perasaan seseorang terganggu, misalnya tersinggung karena ditegur atau takut karena dimarahi atau diancam maka proses mentalnya akan terganggu. Sebaliknya jika semua indera bekerja dengan baik dan perasaan senang maka otak dapat berfungsi secaraoptimal sehingga proses mental dapat berjalan dengan baik. Dengan demikian suasana kondusif merupakan syarat utama dalam kegiatan pembelajaran dengan menghindari bangkitnya siri' ripaka siri dalam diri siswa.

Paparan di atas menggambarkan bahwa konsep siri' yang senantiasa terpatri dalam diri manusia Bugis-Makassar, di samping menjadi sumber motivasi bagi diri peserta didik untuk belajar, juga dapat menjadi landasan bagi dosen dalam menciptakan suasana yang kondusif dalam pengelolaan kegiatan pembelajaran di kelas. Motivasi berprestasi yang timbul dari semangat siri' ini dapat menumbuhkan berbagai kreativitas dan mendorong lahirnya insiatif dari peserta didik.

\section{Konsep Mengenai Budaya Pacce/Passe' (Perikemanusian)}

Pacce' (Makassar), pesse' (Bugis) merupakan nilai budaya Bugis-Makassar. Hamid (1999) mengatakan bahwa siri' dan pacce' adalah dwi konsep yang menjadi ciri individu Bugis-Makassar, mempertahankan keseimbangan antara aib dan harga diri sebagai diartikan oleh siri' dan memelihara rasa kebersamaan dalam kedukaan dan penderitaan setiap anggota masyarakatnya sebagai ditegaskan dalam gagasan pacce. Pacce secara harfiah berarti perasaan pedih dan perih yang dirasakan meresap dalam kalbu seseorang, karena melihat penderitaan orang lain. Pacce' berfungsi sebagai alat peng-galang persatuan, solidaritas, kebersamaan, kesetiaan, rasa kemanusiaan, dan motivasi untuk berusaha, sekalipun dalam keadaan yang sangat pelik dan berbahaya. Hal ini dapat dipahami dari salah satu ungkapan dalam bahasa Bugis yang dikutip oleh Abidin (1999) berbunyi "Nare'ko de'na siri'mu, engkamupatu esse'bauamu" (jikalau tak ada lagi siri'mu, maka pasti masih ada rasa pedihmu dan kasih sayangmu). Ungkapan ini merupakan wujud persahabatan dan rasa pedih yang terpatri dalam kalbu ketika melihat penderitaan orang lain, sehingga menimbulkan iba hati yang sangat mendalam dan mendorong seseorang untuk membantu orang yang sedang menderita.

Pacce' merupakan panggilan hati nurani untuk menyatakan sikap kesetiakawanan sosial terhadap penegakan harkat siri' bersama. Pacce' mendorong dalam kenyataan adanya perbuatan tolong menolong, adanya tuntut bela serta segala kenyataan lain yang mirip pada solidaritas yang mendapatkan hidupnya dari konsep siri'. Konsep pacce' yang diwujudkan sebagai rasa solidaritas untuk membela, membantu sesama diungkapkan dalam bahasa Makassar dengan ungkapan "abbulo sibatang" atau dalam ungkapan Bugis "mali siparappe, rebba sipatokkong, malilu sipakainge". Semangat abbulo sibatang, mengandung makna rasa solidaritas yang tinggi untuk saling membantu, dalam menghadapi setiap tantangan dan kesulitan. Rasa solidaritas tersebut juga disertai semangat saling menghargai yang dalam ungkapan Bugis disebut sipakatau. Sipakatau merupakan wujud dari siri' dan pacce' yang merupakan kesadaran kualitas dari apa yang disebut manusia yang hanya mungkin mengaktualisasi dirinya karena adanya manusia yang lain. Mattulada (1998) mengemukakan bahwa dalam konsepsi sipakatau tertanam makna, nilai dan segala sesuatu yang bersifat kepatutan, norma-norma kualitatif yang amat dijunjung tinggi. Sipakatau merupakan segala perilaku nyata seseorang atau sekelompok orang yang berinteraksi dalam masyarakat.

Kerjasama sebagai wujud abbulo sibatang dan sipakatau, tidak hanya sekedar bekerja bersama, tetapi mereka bahu membahu untuk saling membantu dan saling merasakan penderitaan serta merasakan kebahagiaan bersama. Dalam komunitas Bugis-Makassar, persahabatan karena merasa senasib sepenanggungan dapat berwujud pembelaan terhadap hak sesama. Artinya bila dalam kebersamaan itu ada orang lain yang mencoba mengganggu hak sahabatnya, maka mereka rela mengorbankan jiwanya demi membela hak sahabatnya.

Semangat abbulo sibatang dalam masyarakat Bugis-Makassar, bila diadopsi dalam kegiatan pembelajaran, sejalan dengan Vygotsky yang memandang bahwa semua proses psikologi yang tinggi berasal dari proses sosial, saling memberi 
antar orang. Dengan demikian belajar geografi sosial sebagai suatu proses interaksi diperlukan adanya kerjasama antar peserta didik yang dapat diwujudkan dalam bentuk kelompok. Kerjasama tersebut tidak hanya sekedar bekerja secara bersama, tetapi setiap individu yang terlibat dalam kerjasama tersebut memiliki tanggung jawab masing-masing dan setiap individu saling menghargai antara satu dengan yang lainnya. Menurut Vygotsky bahwa peserta didik sebaiknya belajar melalui interaksi dengan orang dewasa dan teman sebaya yang lebih mampu sehingga dapat mempertinggi perkembangan kognitif. Sedang di sisi lain semangat abbulo sibatang merupakan perwujudan rasa kasih sayang untuk berkerja sama dan saling membantu mengatasi masalah. Dengan demikian terdapat kesamaan pandangan antara Vygotsky dengan semangat abbolu sibatang dalam budaya Bugis-Makassar.

Paparan di atas menggambarkan bahwa semangat abbulo sibatang sebagai perwujudan rasa pacce bila diadopsi dalam proses pembealajaran Geografi sosial, diharapkan dapat meningkatkan prestasi belajar peserta didik. Di samping itu semangat abbulo sibatang juga memberikan dampak sosial terhadap diri peserta didik, yaitu adanya keinginan peserta didik untuk saling membantu dalam mengatasi masalah. Dengan demikian keterlibatan semangat abbulo sibatang dalam proses pembelajaran dapat meningkatkan kecakapan sosial peserta didik.

Bila semangat abbolu sibatang menyatu dengan siri', maka setiap individu senantiasa berusaha membantu anggota kelompok lainnya yang membutuhkan bantuan. Setiap individu selalu berusaha melakukan peningkatan kualitas dalam hal ini berusaha meningkatkan pengetahuan. Dengan demikian setiap individu dalam kelompok senantiasa melakukan koreksi terhadap dirinya dan melihat kelemahan dirinya sendiri, sehingga kelemahan tersebut dapat diperbaiki. Kemampuan melakukan koreksi diri ini merupakan sarana dalam menigkatkan kecakapan personal.

\section{Budaya Bugis Makassar dan Pembelajaran}

Berhasil tidaknya proses pembelajaran ditentukan oleh lingkungan sosial budaya. Dengan demikian dalam pembelajaran diperlukan suasana yang kondusif sehingga peserta didik dapat belajar dengan baik. Suasana kondusif tersebut dapat tercipta bila sesuai dengan latar belakang sosial budaya peserta didik. Hal ini menggambarkan bahwa faktor sosial budaya tidak dapat diabaikan dalam proses pembelajaran. Oleh karena itu dalam proses pembelajaran bagi peserta didik yang berlatar belakang etnis Bugis-Makassar diperlukan strategi pembelajaran yang sesuai dengan budaya Bugis-Makassar.

Proses pembelajaran harus mampu mengimplemetasikan budaya sipakatau. Sikap budaya sipakatau yakni sikap keterbukaan yang berarti saling membuka diri dalam peranan kemanusiaan. Pada prakteknya, sikap ini tercermin dalam wujud interaksi di antara peserta didik yakni adanya saling mengakui segala hak-hak yang dimiliki seseorang tanpa memandang status sosial dan rasa peduli terhadap sesama. Nilai sipakatau mengajarkan untuk senantiasa memperlakukan orang lain dengan baik dan memandang orang dengan segala kelebihannya. Oleh karena itu budaya sipakatau menjunjung tinggi nilai saling menghargai antar sesama, tidak mengenal tindakan semena-mena terhadap sesama, dan bahkan persoalan individu menjadi persoalan bersama.

Konsep siri' merupakan inti kebudayaan Bugis-Makassar. Konsep tersebut oleh Abidin dikelompokkan atas dua bagian yaitu siri' masiri' dan siri' ripakasiri'. Dalam konsep siri' masiri' terkandung semangat untuk selalu berhasil dalam melakukan suatu pekerjaan sehingga dapat bermanfaat bagi diri orang yang bersangkutan dan bermanfaat bagi masyarakat di sekitarnya. Di samping itu konsep tersebut juga senantiasa memberikan semangat hidup yang pantang menyerah dalam menghadapi segala situasi. Hal ini tercermin dari prinsip para pelaut Bugis Makassar, yang berbunyi

'pura ba'barasompe'ku, pura tangkisi' gulikku, ulebbireng telleng na toalie"

Bilamana layarku sudahku kembangkan, kemudiku telah kupancangkan, maka lebih baik tenggelam dari pada balik surut.

Prinsip tersebut senantiasa memberikan semangat untuk bekerja semaksimal mungkin dan penuh pertimbangan sehingga dapat berhasil dalam perkerjaannya. Di samping itu prinsip ini juga memberikan peluang bagi berkembangnya kreativitas. Rasa siri' masiri' yang tertanam dalam jiwa manusia Bugis-Makassar untuk pantang menyerah dalam menghadapi segala situasi baik situasi yang menyenangkan maupun situasi 
yang sangat berbahaya, memberikan tantangan untuk berpikir dan berkreasi sehinggadapat berhasil dalam hidupnya.

Konsep siri' yang kedua adalah siri' ripakasiri', yang merupakan manifestasi perbuatan untuk membela kehormatan demi tegaknya siri' di masyarakat. Siri' ripakasiri' muncul dalam diri seseorang bila dipermalukan di hadapan umum. Dalam diri orang Bugis-Makassar selalu tertanam rasa siri, sehingga bila ia dipermalukan di depan umum, maka mereka biasanya rela mati dengan perkelahian demi menegakkan siri'nya (menegakkan harga dirinya). Oleh karena itu dalam berinteraksi dengan orang Bugis-Makassar, rasa siri' ripaka siri'nya perlu dijaga.

Memperhatikan paparan di atas, maka salah satu hal yang perlu diperhatikan dalam pembelajaran pada diripeserta didik adalah senantiasa memberikan semangat dan motivasi untuk berkarya dengan membangkitkan rasa siri' masiri' dalam peserta didik. Hal ini dapat dilakukan dengan memberikan gambaran keberhasilan para nenek moyang mereka dalam menghadapi segala situasi, termasuk kegigihan para pelaut Bugis-Makassar dalam mengarungi samudra. Di samping itu perlu diperhatikan agar siri' ripakasiri'peserta didik tidak bangkit. Sebab bila siri' masiri'nya dibangkitkan maka peserta didik akan melakukan pembangkangan yang berupa perlawanan fisik atau dapat juga berupa keengganan untuk mengikuti pelajaran.

Bangkitnya siri' ripaka siri' pada diri peserta didik dapat mengganggu konsentrasi peserta didik dalam belajar. Hal ini terjadi karena adanya gangguan fungsi otak, sehingga informasi yang diperoleh peserta didik tidak dapat diteruskan ke otak. Oleh karena itu salah satu jalan bagi terciptanya suasana kondusif bagi anak agar kerja otak peserta didik bekerja dengan baik sehingga dapat menyerap informasi dengan baik, adalah menghindarkan bangkitnya siri' ripaka siri dalam jiwa peserta didik.

Konsep yang berkaitan erat dengan siri' adalah konsep pacce' (Makassar)/pesse' (Bugis). Konsep ini mengandung solidaritas yang tinggi sebagai wujud persaudaraan, baik sesama etnis Bugis-Makassar maupun persaudaraan dengan etnis lainnya. Semangat persaudaraan orang Bugis-Makassar sangat tinggi. Bila ia telah menyatakan bersaudara dengan seseorang walaupun orang tersebut tidak ada hubungan kekerabatan dengan dirinya, maka ia rela mati demi membela saudaranya tersebut. Pacce' merupakan panggilan nurani untuk menyatakan sikap kesetiakawanan social terhadap penegakan harkat siri' bersama. Konsep ini senantiasa memberikan dorongan kepada manusia BugisMakassar untuk hidup tolong menolong, merasakan penderitaan sesama manusia.

Konsep pacce'/passe' diwujudkan dengan semangat sipakatau, yaitu suatu semangat untuk saling menghargai sesama manusia. Di samping itu dalam etnis Makassar dikenal semangat $a b$ bulosibatang, yang merupakan semangat kerjasama dan tolong menolong sesama manusia. Kedua perwujudan pacce'/passé tersebut, baik sipakatau maupun abbulosibatang, tidak hanya sekedar bekerja bersama dan tolong menolong, di dalamnya terkandung semangat saling merasakan penderitaan, perasaan senasib sepenanggungan, serta merasakan kebahagiaan bersama.

Konsep pacce'/passe' ini memberikan gambaran bahwa manusia Bugis-Makassar memiliki semangat kerjasama yang tinggi dalam menyelesaikan suatu permasalahan. Dalam proses pembelajaran semangat ini dapat dijadikan landasan dalam belajar bersama dengan prinsip adanya saling membantu antar sesama anggota dalam kelompok, sehingga kegagalan dan keberhasilan dalam kelompok dirasakan oleh sesama anggota kelompok. Konsep siri' dan pacce' yang sering disebut dwi konsep budaya Bugis-Makassar, memberikan makna perlunya rasa kasih sayang antarsesama manusia. Rasa kasih sayang dalam kehidupan manusia Bugis-Makassar yang dimaksud adalah tidak terlalu keras dalam menghadapi dan juga tidak terlalu lunak. Sebagaimana ungkapan lontara yang dikutip oleh Abidin (1999) yang berbunyi “...janganlah bersikap terlalu manis, sebab engkau akan ditelan bulat-bulat. Jangan juga bersikap terlalu pahit, sebab engkau akan dimuntahkan...". Ungkapan ini merupakan petuah yang mengandung makna bahwa orang Bugis-Makassar, tidak boleh diperlakukan terlampau lunak, karena mereka akan mempermainkan. Mereka juga tidak boleh diperlakukan terlalu kasar dan keras, karena mereka akan membenci dan melawan. Rasa kasih sayang ini dapat diwujudkan dengan memberikan bantuan kepada sesama pada saat dibutuhkan.

Kajian di atas menggambarkan beberapa prinsip yang perlu diperhatikan dalam proses pembelajaran berbasis budaya Bugis-Makassar. 
Prinsip-prinsip yang dimaksud adalah sebagai berikut:

a. Guru/Dosen berusaha menciptakan suasana yang kondusif bagi siswa sehingga siri' ripaka siri' tidak muncul dalam diri peserta didik.

b. Guru/Dosen berusaha membangkitkan siri' ma siri'dalam diri siswa sebagai upaya membangkitkan motivasi peserta didik untuk berprestasi.

c. Wujudkan prinsip Sipakatau dan abbulosibatang (saling bekerjasama) dalam bentuk kerja kelompok. Dalam kerja kelompok tersebut peserta didik diarahkan untuk saling membantu dan saling merasakan pentingnya kehadiran anggota serta kerjasama yang saling menguntungkan. Di samping itu dalam kerja kelompok setiap peserta didik memiliki tanggung jawab individu untuk keberhasilan kelompok.

d. Pimpinan kelompok dipilih dari salah seorang anggota yang memiliki kemampuan lebih disbanding anggota lainnya, sehingga pimpinan kelompok sekaligus bertindak sebagai tutor sebaya.

e. Wujudkan rasa kasih sayang pada peserta didik melalui pemberian bantuan kepada peserta didik yang membutuhkan, baik secara individu maupun secara kelompok. Di samping itu wujud kasih saying juga diberikan dalam bentuk penghargaan kepada peserta didik yang berhasil dan memotivasi peserta didik yang belum berhasil.

f. Penilaian dilakukan terhadap semua aktivitas peserta didik, baik secara individu maupun secara kelompok.

Guru/dosen dapat mengkaji budaya-budaya yang berada dalam lingkungan peserta didik dalam proses pembelajaran, kemudian mengkaji nilai-nilai yang ada dalam budaya tersebut. Guru/Dosen dapat menyampaikan dan menekankan betapa pentingnya nilai budaya-budaya tersebut. Sehingga nantinya diharapkan peserta didik tidak hanya mengerti tetapi lebih menghargai budaya-budaya mereka dan dapat mengambil nilai-nilai yang ada di dalamnya yang berimbas pada pembentukan karakter bangsa. Penekanan pada nilai-nilai budaya ini sangat penting untuk dilakukan oleh guru/dosen. Penekanan yang dimaksud adalah bagaiamana nilai-nilai budaya ini dapat dibiasakan dalam pembelajaran sehingg peserta didik akan menjadi terbiasa dalam menerapkan nilai-nilai budaya tersebut.
Proses pembelajaran yang memperhatikan prinsip siri', pacce, dan Sipakatau diharapkan dapat meningkatkan semangat belajar peserta didik sehingga dapat meningkatkan prestasi belajarnya, menumbuhkan sikap positif dalam hal peningkatan mutu pembelajaran, serta dapat menumbuhkan semangat kerjasama dan tolong menolong dengan sesama dalam kehidupan. Dengan demikian tujuan pembelajaran yang bertumpu pada kemampuan kognitif, kemampuan afektif, dan kemampuan psikomotor diharapkan dapat tercapai. Penanaman nilai-nilai yang terkandung dalam budaya lokal ini diharapkan akan mampu membentuk peserta didik yang memiliki karakter yang mampu bertahan ditengah era globalisasi serta rasa cinta terhadap budaya lokalnya sehingga tidak terkikis dengan derasnya arus globalisasi.

Pendidikan budaya dan karakter bangsa merupakan salah satu upaya untuk mencegah terjadinya degradasi nilai-nilai etika dan moral di kalangan remaja. Keberhasilan dalam membangun karakter peserta didik, secara otomatis membantu keberhasilan membangun karakter bangsa. Kemajuan suatu bangsa tergantung pada bagaimana karakter orang-orangnya, kemampuan intelegensinya, keunggulan berpikir warganya, sinergi para pemimpinnya, dan lain sebagainya. Dengan demikian dapat disimpulkan bahwa pendidikan budaya adalah penting dalam membangun moral dan kepribadian bangsa.

\section{PENUTUP}

Integrasi nilai budaya Bugis Makassar (Siri', Pacce, dan Sipakatau) sangat penting dalam proses pembelajaran. Konsep ini bila dimanfaatkan secara benar dalam proses pembelajaran dapat menjadi pendorong yang kuat bagi peserta didik untuk meningkatkan prestasi belajarnya. pemahaman dan pengaplikasian nilai-nilai budaya Bugis Makassar berfungsi sebagai filter menghadapi era Masyarakat Ekonomi Asean (MEA). Dengan menggali nilai-nilai budaya siri' dan pacce untuk diterapkan dalam pembelajaran diharapkan dapat membangun karakter bangsa didalam setiap peserta didik.

\section{DAFTAR PUSTAKA}

[1] Abidin, Andi ZainaL. 1999. Kapita Selecta Kebudayaan Sulawesi Selatan. Makassar: Hasanuddin University Press.

[2] Atmi. 2013. Kebudayaan dan Pendidikan. Yogyakarta: Diva Press. 
[3] Gaffar, Syam. 2004. Mengartikulasikan Pendidikan Nilai. Bandung: CV Alfabeta.

[4] Geertz. 1992. Nilai dan Etika. Jakarta: PT Gramedia Pustaka Utama

[5] Hamid. 1999. Manusia Bugis Makassar. Jakarta: PT. Gunung Agung.

[6] Mattulada, 1998. Kebudayaan, Kemanusiaan dan Lingkungan Hidup. Makassar: Hasanuddin University Press

[7] Sauri. 2010. Pengantar Kebudayaan Lingkungan dan Budaya Lokal. Yogyakarta: Gadja Mada University Press.

[8] Tilaar, HAM, 1999. Pendidikan, Kebudayaan dan Masyarakat Madani Indonesia. Bandung: PT. Remaja Rosda Karya.

[9] Warsi. 2004. Kearifan Lokal Masyarakat dan Pembangunan. Jakarta: Gramedia.

[10] Zamroni, 2001. Paradigma Pendidikan Masa Depan. Yogyakarta: Bigraff Publishing 